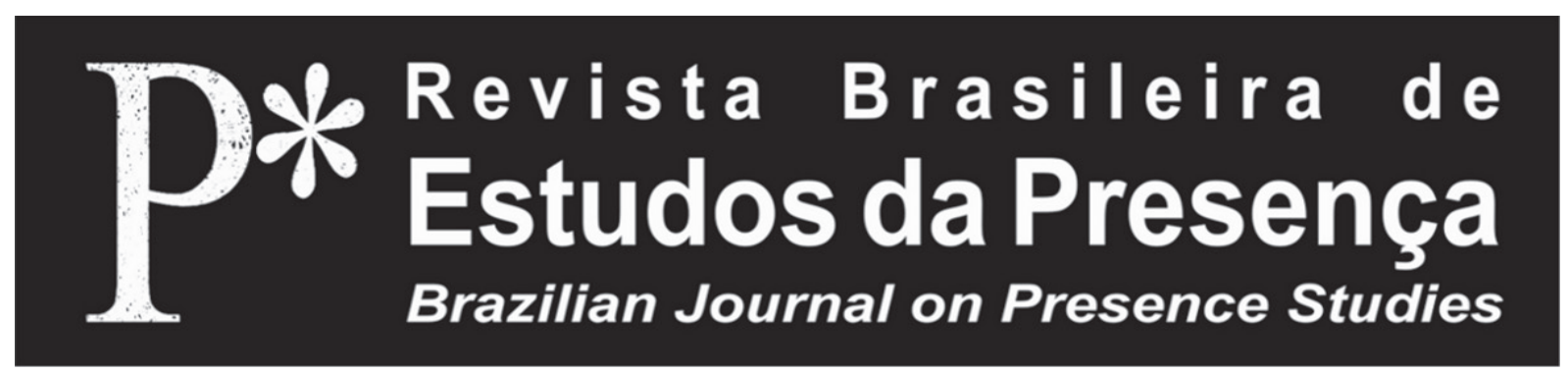

DOI - http://dx.doi.org/10.1590/2237-266042555

ISSN 2237-2660

\title{
Letter for an Exchange between Scientists of Cognition
}

\author{
Victor Emmanuel Jacono \\ University of Rome "La Sapienza" - Rome, Italy
}

ABSTRACT - Letter for an Exchange between Scientists of Cognition - This short essay, written from the point of view of a young theatre maker, pedagogue, and scholar, is presented in the spirit of a letter, addressed primarily at theatre artists and scholars to question their role of scientists in the growing exchange between theatre and neurosciences. In particular the essay highlights the importance of science in a theatre tradition based on the actor's pedagogy, and posits such a tradition as an example of research from which theatre makers could engage in a deep exchange between scientists of cognition. Keywords:Theatre. Pedagogy. Science. Cognition. Epistemology.

RÉSUMÉ - Une Lettre pour un Échange entre Scientifiques de la Cognition-Ce court essai, écrit du point de vue d'un jeune performer, pédagogue et chercheur, est présenté dans l'esprit d'une lettre, adressée principalement aux artistes et chercheurs du théâtre, à s'interroger sur leur rôle des scientifiques dans l'échange croissant entre théâtre et neurosciences. En particulier, l'essai met en évidence l'importance de la science dans une tradition théâtrale basée sur la pédagogie de l'acteur et postule une telle tradition comme un exemple de recherche, à partir de laquelle gens du théâtre pourraient s'engager dans un échange profond entre scientifiques de la cognition.

Mots-clés:Théâtre. Pédagogie. Science.Cognition. Épistémologie.

RESUMO - Carta por um Intercâmbio entre Cientistas da Cognição - Este breve ensaio, escrito do ponto de vista de um jovem realizador teatral, pedagogo e estudioso é apresentado com o espírito de uma carta, endereçada fundamentalmente a artistas e estudiosos do teatro para questionar seu papel como cientistas no crescente intercâmbio entre teatro e neurociência. Particularmente, este ensaio destaca a importância da ciência em uma tradição teatral embasada na pedagogia do ator e propõe essa tradição como um exemplo de pesquisa a partir da qual os realizadores teatrais poderiam se engajar em um intercâmbio profundo entre cientistas da cognição.

Palavras-chaveJeatro. Pedagogia. Ciência. Cognição. Epistemologia. 
The present essay calls especially upon theatre artists and scholars to reflect on their potential role as scientists in the growing exchange between the fields of theatre and cognitive neuroscience.

In order to define such a scientific role, the discussion draws especially upon the actor's pedagogy as conceived by the Italian theatre historian Fabrizio Cruciani in terms of a process of creative growth which the actor, as an individual human being, undergoes autonomously and scientifically. The definition of a scientific approach in the theatre also draws upon theories from neurobiological studies which point to a possible conception of science in terms of the systematic application and development of basic cognitive faculties. It is understandable that such an unorthodox conception of science will be met with scepticism and criticism, not least among those who still find it difficult to reconcile the arts and the sciences upon a common epistemological ground. Even so, the scope of the essay is not to fuel the unending Arts-versus-Science debate. Rather, in full respect for scientific rigor, it seeks to present particularly the theatre researcher with a conception of science and theory that is rooted both in the tradition of the actor's pedagogy and in the human being's basic cognitive faculties. Such an awareness, I posit, would potentiate the contribution of theatre makers and scholars in the exchange between scientists of cognition.

Calling the present essay a letter is a gesture eliciting the spirit of increasing dialogue between the fields of theatre and cognitive neuroscience. This letter, however, is particularly addressed to theatre makers, scholars, and students. In this sense, I have also been inspired by the Italian theatre scholar, Ferdinando Taviani, who, over twenty years ago, published his Lettera su una Scienza dei Teatri (Taviani, 1990). I consider Taviani's lettera to be of utmost epistemological importance for theatre scholarship, for two main reasons. The first reason is the way in which he discusses the concept of science to question the very methodology of theatre studies. The second reason concerns the solution he indicates: drawing especially upon Eisenstein's theory of vertical montage and Eugenio Barba's Theatre Anthropology, Taviani proposes a scientia which looks at diverse theatre cultures to identify and study 
recurring patterns of behaviour (Taviani, 1990, p. 180) across the multiple poietic levels of performance ${ }^{2}$. The present essay, however, focuses primarily on the issue of science in theatre studies.

In his letter, Taviani criticizes those theatre scholars who, in search of scientific badges for their work, would readily supply the methodological and terminological instruments lacking in their field with instruments which have been tried and tested by disciplines of established scientific authority (Taviani, 1990, p. 178-179). I, of course, agree with Taviani that the exhibition of such scientific badges is by itself no certificate of scientific validity. To a certain extent, Taviani's criticism could be compared to the stance taken by Alan Sokal and Jean Bricmont in Fashionable Nonsense: "[...] we are not against extrapolating concepts from one field to another, but only against extrapolations made without argument - or throwing around scientific jargon in front of [...] non-scientist readers without any regard for its relevance or even its meaning" (Sokal; Bricmont, 1998, p. x). It is important to keep such traps as those highlighted by Taviani, Sokal, and Bricmont in mind even in the context of the growing theatre-neuroscience exchange, although we could safely state that the cognitive sciences are far from becoming fashionable in theatre. This is also due to the widespread and, in my opinion, generally undue scepticism and distrust with which many in the Humanities still regard the Natural Sciences. One might add that the scepticism and distrust is indeed mutual. As stated in the introductory paragraph, however, it is not within the scope of the present essay to fuel the complicated and never ending Arts-versusScience debate ${ }^{4}$. Presently, the discussion is merely pointing out the distinction between lending theatre matters to methodological and terminological instruments from disciplines of established scientific authority and engaging "[...] as scientists”, as Gregory Bateson would put it (Bateson; Bateson, 2005, p. 192), with questions arising within the field of theatre. Operating "as scientists" in the theatre does not imply claiming the status of Science for theatre'. Following Bateson's advice rather implies fostering epistemological awareness and striving for clarity and precision in the distinctions and connections, the maps, models and experiments, the measurements and the evaluations we make as we investigate the human condition, also in the theatre. 
Moreover, with this piece of Batesonian advice in view, I posit that theatre artists and scholars could adopt a science which emerges from the individual's cognitive experience as informed by the essential constraints of theatre making. In this sense, calling the present essay a letter also stands as a gesture to highlight the subjective and relational (not relativistic) dimension of scientific research. Beyond the epistemological debate on subjectivity versus objectivity in research ${ }^{6}$, the reference to subjectivity here points at the importance of difference, that difference in the cognitive experiences and practices of each individual which is necessary for the exchange among scientists of cognition. Thinking of the exchange between theatre and cognitive neuroscience, the present letter/essay echoes Jean-Marie Pradier's observation during the $3^{\text {rd }}$ International Conference of Dialogues between Theatre and Neuroscience, that there can be no effective dialog between disciplines or fields of study, but only between individuals, different subjects who may share a common question or problem and who share or would be willing to share a history of research relationships, even when still struggling to find a common language. The present letter/essay is, therefore, also an opening to correspondence, awaiting for a reply.

As a young theatre maker, both as a performer and an educator, my main research interest lies in pedagogy, specifically in the pedagogy of the actor ${ }^{7}$. The actor's pedagogy is different to acting school, meaning the place where an apprentice learns the acting skills necessary for him to do well on stage. Pedagogy is more akin to the scientist's formation, an ongoing process whereby the actor/scientist acquires the skills necessary to conduct an ongoing, systematic research in his work, in order to keep on questioning and learning to learn.

In my research I was lucky to have come across the work of the Italian theatre historian and scholar Fabrizio Cruciani, who dedicated good part of his studies to investigate pedagogy in the theatre (Cruciani, 2006). The actor's pedagogy as the research of the actor/scientist is a concept I owe particularly to Cruciani's writings. He took particular interest in the work of Stanislavski and Copeau, comparing their research to the insights of nineteenth and twentieth century innovators in child education, such as Pestalozzi, Froebel, 
Montessori, and Dewey. From Cruciani's work we can draw a precise definition of the actor's pedagogy and identify some distinct elements: it is a process of creative growth which the actor, as an individual human being, undergoes autonomously and scientifically. Let us look at these elements one by one.

The actor's pedagogy is seen as a process of creative growth. Therefore, not the mere accumulation of knowledge that and knowledge how, but a process which develops, indeed renews the actor himself as a dynamic corpus of knowledge. I am therefore positing an understanding of knowledge as being at one with the knower and his potential for action ${ }^{8}$. The actor undergoes such a process of creative growth as an individual human being. We need not take the concept of individuality in the individualistic sense of the single person against the community, against society. Instead we can think of it in the etymological sense, from the Latin root individuum, referring to an in(-)divisible entity, hence underlining the actor's integrity and complexity. A complex dynamic corpus such as every living being is. Pedagogy is a process the actor undergoes autonomously. The basic idea here is that nobody teaches anyone anything. Again, this does not mean that we learn alone, separated from the world, in a vacuum. It implies that growing, developing, learning is not determined by external factors but it is self-determined, that is determined by the complexity of dynamic structures which the individual is. These structures change in relation to the stimuli encountered in the environment. We can, for instance, refer to Gregory Bateson's concept of information as "[...] a difference that makes a difference" (Bateson; Bateson, 2005, p. 17), a difference in the environment which stimulates, but does not determine, a difference in the dynamic structures which constitute the self. Neurobiology, beginning with the work of Maturana and Varela has provided important insights in this sense with the theories of autopoiesis and structural coupling?

What I presently wish to focus upon, however, is the last element, the actor's pedagogy as a scientific process, because, in my opinion, it addresses in a more direct way the potential that the dialogue with neuroscience has for theatre makers and theatre scholars. That the actor's pedagogy is a scientific process does not imply the application of the theories, terminology, and methods of a 
science such as physics, biology or neuroscience for that matter. Let us keep Bateson's lesson in mind: it is not a matter of talking science about art but of working as scientists in art. Many theatre historians like to debate on the influences Science has had on Stanislavski and on Meyerhold ${ }^{10}$. Indeed, the work of these two theatre directorpedagogues already constitutes an important example of how the brain physiology and psychology of their time influenced the innovative research which they conducted in the theatre in the early twentieth century. But reference to such scientific theories (or other non-scientific theories for that matter) does not define or explain the science of Stanislavski or Meyerhold. As Cruciani points out, for them research was inevitable because they had no prefabricated, readymade acting methods to teach ${ }^{11}$.

Hence, the science of Stanislavski, Meyerhold, and Copeau, and all those who followed their example in the tradition of the actor's pedagogy, is more basic. Their science entailed the systematic (methodical), albeit subjective, development and exercise of their basic cognitive faculties: distinction or the ability to recognize difference, to compare; connection, the ability to recognize relationship, a recurring pattern; prediction, the basic ability to foresee outcomes before they actually happen; experiment and evaluation, the ability to test hypothesis and to measure how close or far are results from the outcomes predicted. And the pioneers of the actor's pedagogy systematically exercised and developed these basic cognitive faculties performatively, within the essential condition of theatre making, i.e. always in view of the actor-spectator relationship.

As theatre performers (lest we forget that Stanislavski, Meyerhold, and many in the line of director-pedagogues which followed upon their footsteps began their research as actors) they had to act as human beings on stage under the gaze of the spectator. Such a condition presents the actor with a series of problems which he has to be able to see, to predict and to tackle through a careful analysis of action which is tested actively in the poiesis, in the creation and representation of action. Thus, as an actor I actually find myself working on concentration, attention, memory, action and reaction, which implies that I need to understand human cognition if I am to organize it mindfully - and by human cognition I mean human 
knowing, acting, relating, living - in order to be able to play with it, to model it, to test its potential on stage. Of course, there is so much that I cannot see with my theatre instruments, so I read, I study, and look into what artists from other disciplines have to say, but also what physiologists have to say, what psychologists have to say, what yogis, philosophers, sociologists, etc. have to say, because they may have the scientific instruments to sound those levels of organization or those aspects of the creative process which would otherwise remain hidden to me. Seeing (theory) already makes an important difference which brings about a difference in the way I go about my work as a theatre artist and pedagogue.

Looking at the creative process also through the instruments of other disciplines, however, should not lead to my abdicating from working with scientific rigor when using my instruments: the exercises and strategies which I devise or borrow to refine my acting skills during training or during stage experiments in rehearsal and performance. As a theatre maker I should not abdicate from generating my own theory on the dynamics of the phenomena I am seeking to understand and represent. All the scientific theories and methods and terminologies which I (need to) borrow from other disciplines and fields of inquiry should not replace my instruments. On the contrary, they will inform my instruments, they will make an important difference in so far as they allow me to get a glimpse, to look and perhaps to see, beyond my limited means. After all, every scientist has to come to terms and be aware of the limits of his instruments. If we looked at cognitive neuroscience itself, for instance, we would soon realize what an intricately interdisciplinary enterprise it is, involving biologists, psychologists, geneticists, physicists, engineers and so on. But I have to keep looking as a scientist in my art of theatre making.

How does one develop a scientific mind-set? It is not the same as asking how one learns a scientific method, because that is not the business of pedagogy as we have defined it here: an individual, autonomous, scientific process of creative growth. But how to look and to operate as a scientist in theatre making, that yes - can that be taught? In relation to this question I refer to the work of Odin Teatret director, Eugenio Barba, who holds that knowledge of the 
principles identified at the pre-expressive level of the performer's work (the focus of Barba's Theatre Anthropology) enables "[...] learning to learn" (1995, p. 9). But can we really teach "learning to learn"? Can we teach the actor to cultivate such a scientific mind-set, besides teaching him acting skills and training instruments? Practically the same dilemma was posited by Stanislavski in My Life in Art, but these are constant questions and problems which concern the actor's pedagogy today. How can I teach the importance of operating as a scientist in one's art? How can I make actors forget commonplace, school-day myths about science? How can I convince them not to be afraid of the word science, or of theory? As the etymology of the word suggests, theory, from the Greek root thea (which is also at the root of the word theatron, theatre), is essentially the ability to see. Can I teach seeing, looking at cognition in performative processes scientifically?

In the preface to Gabriele Sofia's Le Acrobazie dello Spettatore (2013), Barba wittily compares scientific thought to mythology, i.e. stories ${ }^{12}$ which superimpose names (terms) and geometries (patterns) upon the fleeting dynamics of the creative process in performance, in the attempt to capture, to hold such ephemeral dynamics in view. Barba's comparison reminded me of a story which occasionally (not always, depending on the pedagogical needs that I sense) I like to tell people attending my acting workshops. I borrowed this story, so to speak, from a book by the Colombian neuroscientist, Rodolfo R. Llinás, The I of the Vortex (2002). I would call it my favourite myth of the brain, and it goes roughly as follows.

Once upon a time, there was a creature which had to move about in its environment in order to stay alive (notice that the story places motricity as a primary factor, at the genesis of cognition). This creature, however, had not developed its nervous system and its sense organs yet. When it bumped into food, it ate, and when it bumped into danger, say a predator, it got eaten. With no nervous system and no sense organs it just could not see things coming and chance ruled the day. As an analogy, some of the readers my age or older would remember those toy robots which changed direction only once they had already hit the wall. This simple 
living creature behaved somewhat like a toy robot which reacted only when it had already hit the wall, then it would come to the edge of a staircase and... Oops! Too late! What happens when this creature starts developing its sense organs and nervous system? It can now see, predict, i.e. it can scan or sound its environment and use traces of past experience (memory) to plan its moves. As Llinás points out, the brain is primarily an organ for prediction (2002, p. 3). It allows us to gain cognitive space/time, to move in the space of potential action, between stimulus and response.

Upon reading Llinás' story of the brain it occurred to me that gaining cognitive space/time is precisely what theory does, it allows me primarily to see and predict, as Barba again points out in his preface to Sofia's book. Of course, this cognitive space/time has reached such a high level of sophistication in the human being, who could therefore develop language and with language myth, writing, philosophy or science, geometry, mathematics, all the way up to the cutting edge technology for weather forecasts or brain imaging.

The only problem is that early in our school days we learn that theory, to borrow a definition from the Oxford dictionary, is "[...] a supposition or a system of ideas intended to explain something, especially one based on general principles independent of the thing to be explained ${ }^{13}$ " (Oxford Dictionaries, s.p., 2014) and many often translate such a concept as something opposed to practice, to concrete action. Only if we are lucky shall we come across educators who will make us question what theory does, the potential of theory, educators who will make us look at the basic faculties which this cognitive space/time gives us, enabling us to see, i.e. to distinguish, relate, predict, experiment, evaluate. To measure and do before trying - not that such cognitive dimension does not in itself consist of a concrete experience and intervention upon the cognizing self. To act virtually, potentially, albeit always concretely, in view of action. All science, all systems of knowledge build systematically upon these basic cognitive faculties which we all exercise, unawares most of the time, in everyday life, when crossing a road, when preparing a meal, when planning our travels or a series of lectures, during training or rehearsals ${ }^{14}$.

In this sense, it is interesting to note the choice of words with which Chris Chambers, a neuroscientist from the University of 
Cardiff, commented on a study again highlighting the predictive function of the brain: "[...] this work highlights something that is becoming increasingly apparent in neuroscience, that a major part of brain function in decision-making is the testing of predictions against reality - in essence all people are 'scientists' ${ }^{15}$ " (Gallagher, n.p., 2011). The suggestion that we are biologically equipped for science also comes out in Understanding the Brain: the birth of a learning science, an OECD/CERI report ${ }^{16}$ on the relevance of studies in cognitive neuroscience for education policy and practice. Capitalizing on the infant's neurocognitive predisposition, not only for language, but also for "[...] play, spontaneous exploration, prediction, and feedback", which are developed already in the infant's early learning environments, the report advises schools to provide "[...] even the youngest children with the chance to be scientists and not just tell them about science" (OECD, 2007, p. 43, italics by the author). Looking back at the history of the actor's pedagogy, one recalls the work of Jacques Copeau with children, not in order to train them in stage art from a young age, but to learn lessons in creativity from them, by observing their games (Aliverti, 2009).

The above considerations bring me back to my experience of various actor-training workshop contexts over the past few years, especially in Italy. I have had the opportunity of teaching and observing actors in training both in the so-called research/group theatre contexts and in the more traditional theatre academy contexts. Most participants generally fall under two main groups. Primed as they may be by their education, the philosophically or scientifically initiated will come prepared branding their baggage of theories about this and that; the philosophically or scientifically uninitiated will come reciting mantras (in the sense of formulas for self-protection) such as knowledge is a matter of doing, creativity is irrational, chaotic, acting is a matter of feeling, of intuition, why waste our time talking when we could be learning a new exercise?, and so on. They will come to class prepared with their personal experience, including the theatre they have in mind, and are inclined not to stray too far from their comfort zones. That is understandable, of course. We are all familiar with the economy of habit, in its cognitive sense: it allows us to spare resources, to save time, and that can be useful, or fatal (when 


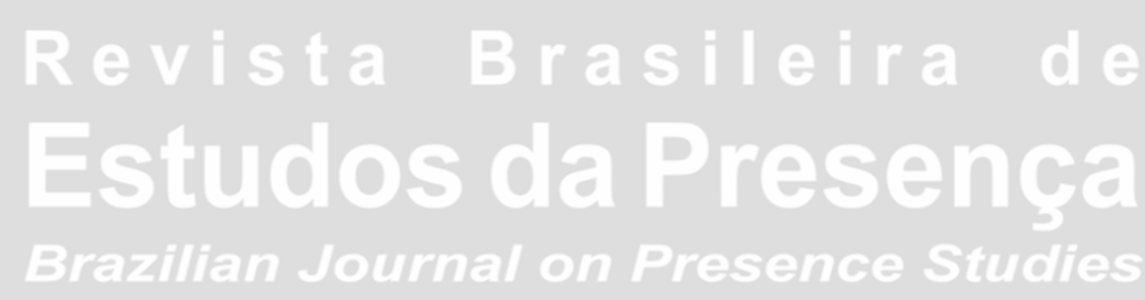

the habit does not match the situation), as the chance may be, in moments of imminent danger. Armed with theory or no theory, either way students often come to defend their ideas, their habits (or lack thereof) and it is difficult to make them see. Sometimes, during a task that has become familiar, for instance, when simply walking across a space, or doing an exercise they have become extremely familiar with, which they start repeating mechanically, I blindfold them, and seeing is often reawakened in the process. Reading Llinás' story of the brain I also began seeing the sense of this strategy in new light. So sometimes I accompany this exercise by also telling the students the story of the brain, and I find that it helps some of them at least to start looking at science and theory differently.

To me the actor's pedagogy is the space in which no excess of resources should be spared in order to stimulate theory - not prefabricated scientific or philosophical theories about this or that, pure or empirically tested as they may be, but the praxis of theory, stimulating the faculty to look at performative processes as scientists (or philosophers, no important difference between these two categories in this case). To mindfully activate the sophisticated cognitive potential which we have developed as human beings and to exercise that potential in favour of creative visions. Not the obsession with novelty which pervades academic, artistic, and scientific enterprise alike, but visions which I believe could produce valid alternatives to the current education economy, of education in general (not just artistic education), to the economy which regulates the knowledge industry, the so-called creativity industries, and so on. For instance, looking at recent papers on the impact of neuroscience on education ${ }^{17}$, on the current drive to inform educational programmes with recent findings in brain studies, I was pleased to see that the call to look further into the neurobiological basis of education was accompanied by the urgency for educators to develop a more critical look at the factors which affect learning and education at all levels. What emerges is the need for educators and policy makers to sharpen their scientific vision on the complexity of phenomena, not simply to follow the latest trend in education theory.

The point which the neuroscientist Steven Rose raises in his book, The Future of the Brain, is important in this sense. 
Commenting about learning disorders included in the United States based Diagnostic and Statistical Manual in the past few years - disorders such as oppositional defiance disorder, disruptive behaviour disorder and attention deficit hyperactivity disorder (ADHD) - Rose describes the wide-spread use of Ritalin, the drug used to counteract ADHD, as "[...] an increasing world-wide epidemic" (2005, p. 6). Indeed, he questions whether such a general and wide-spread administration of the drug constitutes "[...] an appropriate medical/psychiatric approach to an individual problem, or a cheap fix to avoid the necessity of questioning schools, parents and the broader social context of education?" (2005, p. 6).

Does neuroscience (along with any other theoretical trend in the field of theatre) risk becoming a cheap fix also for theatre scholars and artists? I believe this is an important question to keep in view, without however diminishing the importance of insights we might gain from the exchange between researchers from the two fields. In relation to the dialogue with neuroscience, following the example of the actor's pedagogy, as we have defined it here, would require not only an effort on the part of theatre makers and neuroscientists to gain a better understanding of each other's field of research and to find a common language - which is very important of course. It calls especially upon the theatre maker to sharpen his scientific skills, to stimulate the praxis of theory already within the special conditions of his art. I believe that only in that way can he and his interlocutors gain the greatest benefit from the dialogue between theatre and neuroscience. Only in that way can the theatre maker and scholar be in a position to truly reciprocate the insights coming from neuroscience with insights that would allow the neuroscientist to gain access to performative processes in a way which, perhaps, the latter could not see, because previously he could only look upon them as an uninformed spectator ${ }^{18}$. In this way I believe that the science of theatre makers can make an important difference in the science of cognition.

To conclude, the most important difference that the encounter with cognitive neuroscience has made in my practice as a young theatre artist, as an educator, and a scholar has been, above all, the stimulus to open and sharpen my look as a scientist upon performative 
processes, upon creativity, and to encourage my students to do likewise. Far from presenting me with ready-made solutions or reducing the complexity of the creative processes which I seek to stimulate and understand, my experience of exchange with scientists of cognition has enabled me to start addressing important problems, but also possible strategies, that I had previously not even considered. Moreover, looking at science and theory from the perspective of the human being's ability to work upon and sophisticate his cognitive faculties has been an important lesson. Such a demystified perspective of science fosters awareness, empowerment, but also a greater sense of responsibility and of wonder, which characterizes the actor's pedagogy as we have defined it here - above all a sense of responsibility and wonder towards the creative potential of human encounter, also in the theatre. 


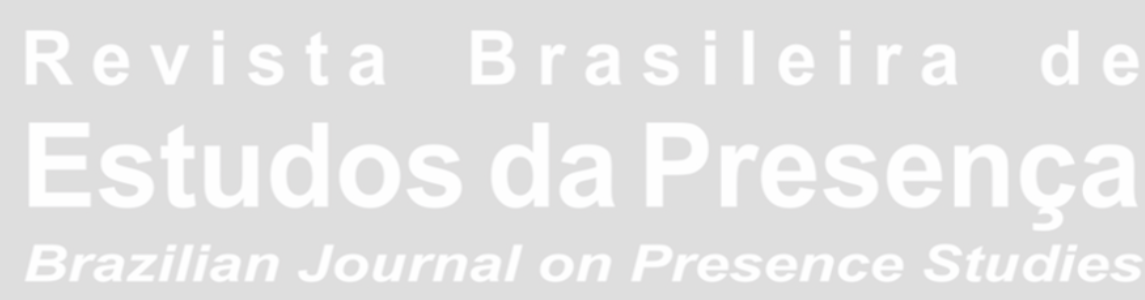

\section{Notes}

${ }^{1}$ The essay is an extended version of a paper entitled Le Neuroscienze e la Pedagogia dell'Attore, presented during the 5th International Conference of Dialogues between Theatre and Neuroscience held at the University of Rome "La Sapienza", in June 2013.

${ }^{2}$ In Taviani's lettera, one might recognize the epistemological proximity of Barba's Theatre Anthropology with the thought of anthropologist Gregory Bateson, who placed metaphor and the recurrence of pattern at the centre of his epistemology (Bateson; Bateson, 2005). For a comparison between Barba's Theatre Anthropology and Bateson's cybernetic epistemology see Towards a Cybernetic Understanding of "the Performer's Work upon Himself" (Jacono, 2004, unpublished undergraduate dissertation).

${ }^{3}$ To be precise, Sokal and Bricmont's criticism, as indicated in the subtitle of their 1998 publication, targets particular instances of postmodern intellectuals' abuse of science, although it does not seek to dispel the general validity of postmodern thought. Even so, Sokal and Bricmont's book has stirred a lot of controversy on account of it being perceived as an attack on postmodernism as a whole, a matter which however lies beyond the scope of the present discussion.

${ }^{4}$ Indeed, accusations of scientism/reductionism and relativism/mysticism continue to be hurled across the arts-science divide, with some arguing that the exchange between the two fields is impossible due to fundamental epistemological differences. Others, however, have long argued strongly in favour of exchange and mutual influences to counteract the fragmentary image of the human condition brought about by the growth of specialization (Walker, 1964; Bohm; Peat, 1987; Lehrer, 2008).

${ }^{5}$ Even outside the sphere of postmodern criticism, philosophers of science such as Alan F. Chalmers (1999) and Samir Okasha (2002) seem to agree that notwithstanding the social status it enjoys, "[...] science is a heterogeneous activity, encompassing a wide range of different disciplines and theories. It may be that they share some fixed set of features that define what it is to be a science, but [...] a simple criterion for demarcating science from pseudo-science is unlikely to be found" (Okasha, 2002, p. 16-17).

${ }^{6}$ For a discussion on the subjectivity and relationality of scientific enquiry, see the important interdisciplinary publication of physicist Ilya Prigogine and philosopher Isabelle Stengers, La Nuova Alleanza: metamorfosi della scienza (1999).

${ }^{7}$ Although I am aware that pedagogy is a loaded term and that it has been addressed from different sociological perspectives, it is here being strictly defined according to the focus of Cruciani's studies as a process of creative growth which the actor, as an individual human being, undergoes autonomously and scientifically.

${ }^{8}$ See Performer Knowledge and Science (Jacono, 2012), which draws particularly upon the research in performative processes of Jerzy Grotowski (2001), and the neurobiology of Humberto Maturana and Francisco Varela (1998) to relate the concept of knowledge with being and action. Increasing importance has been given to the centrality of action to cognition in recent studies in cognitive neuroscience (Rizzolatti; Sinigaglia, 2006; 2010; 2011; Berthoz; Petit, 2008). 
${ }^{9}$ Autopoiesis, according to Maturana and Varela, is what truly characterizes living beings: an organization which enables them to continuously produce themselves, i.e. to renew the dynamic structures which they are - a biological theory which reconciles identity and change. Due to such a biological organization, living beings behave as closed systems, in that internal changes may be triggered by external perturbations but are solely determined by internal structures. What enables communication between such operationally closed systems is structural coupling: "The nervous system and the whole organism may be closed, but if they have a plastic structure that changes in the course of the interactions they undergo, then a history of relations may unfold that does not intersect with the internal dynamics of the nervous system or the organism (and vice versa)" (Maturana; Poerksen, 2002, p. 85). A more elaborate discussion of these topics can be found in Relationships, Transmission, Improvisation (Jacono, 2011), and in the unpublished doctoral thesis, Questioning how Knowledge Acts: the relationship between the performer's pedagogy and cognitive neuroscience (Jacono, 2012). The thesis refers especially to the pedagogical principles of Stanislavski and Copeau, and compares the Socratic idea of learning as a form of remembering (in Plato's Meno) to the theories put forward by Grotowski (2001, p. 379) and the Colombian neuroscientist Rodolfo R. Llinás (2002, p. 176).

10 See Whyman (2008) and Gabriele Sofia's unpublished doctoral thesis, La Relazione Attore-spettatore. Storia, ipotesi e sperimentazioni per lo studio del livello neurobiologico (2011), particularly the first part dedicated to a historical overview of relationships between theatre and the brain sciences.

${ }^{11}$ Cruciani gives an articulated explanation of this phenomenon in a round table conference with Franco Perrelli entitled Attore: c'è qual cosa di sbagliato nelle pedagogie del '900?. The conference was held in Lecce on 3 December, 1986, within the cycle of seminars Paesaggi, Passaggi, Deliri Teatrali del Primo Novecento, organised by Astragali Teatro. An unpublished transcript of the conference by Serena Stifani, revised by Victor Jacono and Clelia Falletti, is kept at the Archives of Astragali Teatro (Lecce). See also Jacono (2012).

${ }^{12}$ Again, some might find exception with Barba's comparison of science with mythology (Sokal; Bricmont, 1998, p. 1). Even so, in my opinion here Barba is not trying to downgrade science. Fully aware of the scepticism with which the community of theatre artists and scholars at large regard the sciences, and of the positive influence that the sciences have nevertheless had upon his own work, to me it appears that he is rather adopting a subtle strategy to bridge the divide, in view of Sofia's important, albeit challenging, contribution to theatre studies.

${ }^{13}$ Definition taken from Oxford Dictionaries online. Available at: <http://www. oxforddictionaries.com/definition/english/theory?q=theory>. Accessed on: 17 feb. 2014.

${ }^{14}$ In this sense, it is interesting to note Albert Einstein's observation that "[...] the scientific way of forming concepts differs from that which we use in our daily life, not basically, but merely in the more precise definition of concepts and conclusions; more painstaking and systematic choice of experimental material; and greater logical economy" (Einstein, 1940, p. 487). 


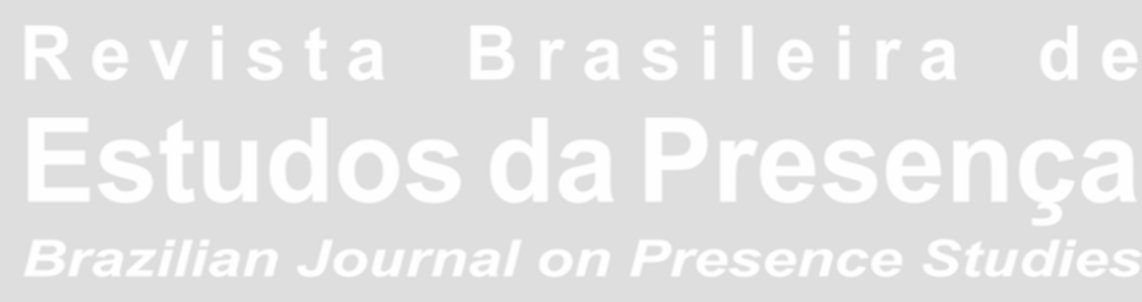

${ }^{15}$ Dr. Chambers' observation is quoted in James Gallagher's BBC News Health review, Brain 'Rejects Negative Thoughts'(09 oct. 2011). Available at: <http://www.bbc.co.uk/news/ health-15214080>. Accessed on: 01 feb. 2014.

${ }^{16}$ The publication was issued by the Centre of Educational Research and Innovation (CERI) of the international Organization for Economic Co-operation and Development (OECD).

${ }^{17}$ See particularly the collection of papers published in Educational Philosophy and Theory, v. 43, n. 1, 2011.

${ }^{18}$ A case in point, documented by Sofia (2013, p. 83), is illustrated in the discussions which took place between theatre makers and scholars forming part of the EMA-PS project and the neuroscientists Giacomo Rizzolatti and Maria Alessandra Umiltà, during international conferences held in Malta in 2005 and 2006. In order to illustrate the workings of the mirror mechanism, Umiltà and Rizzolatti presented an experiment testing motor activation in the macaque monkey brain as the animal watched an experimenter grasping an object concealed behind a screen. Mirror neuron activity peaked when the experimenter actually grasped the object, but did not peak when the experimenter merely mimed the grasping of an object that was not there. From their knowledge of a trained actor's capacity to convincingly render the dynamics of an action even in mime (i.e. the dynamics of grasping also in the absence of the object being grasped) the theatre researchers could not help speculating that, had the experimenter been a trained actor miming the grasping action, the monkey's mirror neuron activity would probably have peaked even in the absence of the object behind the screen. Not only did the neuroscientists consider the relevance of such an observation but, as noted by Sofia (2013, p. 90), they also started employing trained actors in similar experimental protocols.

\section{References}

ALIVERTI, Maria Ines (Org.). Artigiani di una Tradizione Vivente. L'attore e la pedagogia teatrale. Firenze: VoLo Publisher (La Casa Usher), 2009 [1909-1929].

BARBA, Eugenio. The Paper Canoe. A guide to theatre anthropology. London and New York: Routledge, 1995.

BATESON, Gregory; BATESON, Mary Catherine. Angels Fear. Towards an epistemology of the sacred. Cresskill: Hampton Press, 2002 [1987].

BERTHOZ, Alain; PETIT, Jean-Luc. The Physiology and Phenomenology of Action. Oxford: Oxford University Press, 2008 [2006].

BOHM, David; PEAT, F. David. Science, Order, and Creativity. London and New York: Routledge, 2000 [1987].

CHALMERS, Alan. What is this Thing Called Science?. Maidenhead: Open University Press, 1999.

CRUCIANI, Fabrizio. Registi Pedagoghi e Comunità Teatrali del Novecento. Roma: Editoria \& Spettacolo, 2006 [1995]. 
EINSTEIN, Albert. Considerations Concerning the Fundaments of Theoretical Physics. Science, New York City, The Science Press, v. 91, n. 2369, p. 487-491, may 1940.

GALLAGHER, James. Brain “Rejects Negative Thoughts”. BBC News Health, [s.1.], 09 oct. 2011. Available at: <http://www.bbc.co.uk/news/health-15214080>. Accessed on: 01 feb. 2014.

GROTOWSKI, Jerzy. Performer. In: SCHECHNER, Richard; WOLFORD, Lisa (Org.). The Grotowski Sourcebook. London and New York: Routledge, 2001. P. 376-380.

JACONO, Victor. Relationships, Transmission, Improvisation. In: FALLETTI, Clelia; SOFIA, Gabriele (Org.). Nuovi Dialoghi tra Teatro e Neuroscienze. Roma: Editoria \& Spettacolo, 2011. P. 191-203.

JACONO, Victor. Performer Knowledge and Science. In: FALLETTI, Clelia; SOFIA, Gabriele (Org.). Prospettive su Teatro e Neuroscienze. Dialoghi e sperimentazione. Roma: Bulzoni, 2012. P. 118-129.

LEHRER, Jonah. The Future of Science... Is Art?. Seed, [s.1.], 16 jan. 2008. Available at: <http://www.seedmagazine.com/news/2008/01/the_future_of_scienceis_art. php?page=all\&p=y>. Accessed on: 18 jun. 2008.

LLINÁS, Rodolfo. I of the Vortex. From neurons to self. Cambridge and London: The MIT Press, 2002 [2001].

MATURANA, Humberto R; POERKSEN, Bernhard. From Being to Doing. The origins of the biology of cognition. Heidelberg: Carl-Auer Verlag, 2004 [2002].

MATURANA, Humberto; VARELA, Francisco. The Tree of Knowledge. The biological roots of human understanding. Boston and London: Shambala Publications Inc., 1998 [1987].

OECD, CERI. Understanding the Brain. The birth of a learning science. Paris: OECD, 2007.

OKASHA, Samir. Philosophy of Science. A very short introduction. Oxford and New York: Oxford University Press, 2002.

PRIGOGINE, Ilya; STENGERS, Isabelle. La Nuova Alleanza. Metamorfosi della scienza. Torino: Giulio Einaudi, 1999 [1978].

RIZZOLATTI, Giacomo; SINIGAGLIA, Corrado. So quel che Fai. Il cervello che agisce e i neuroni specchio. Milano: Raffaello Cortina, 2006.

RIZZOLATTI, Giacomo; SINIGAGLIA, Corrado. The Functional Role of the Parieto-frontal Mirror Circuit: interpretations and misinterpretations. Nature Reviews Neuroscience, London, Nature Publishing Group, v. 11, p. 264-274, apr. 2010.

SINIGAGLIA, Corrado; RIZZOLATTI, Giacomo. Through the Looking Glass: self and others. Consciousness and Cognition, [s.1.], Elsevier, v. 20, p. 64-74, 2011.

ROSE, Steven. The Future of the Brain. The promise and perils of tomorrow's neuroscience. New York: Oxford University Press, 2005. 
SOFIA, Gabriele. Le Acrobazie dello Spettatore. Dal teatro alle neuroscienze e ritorno. Roma: Bulzoni, 2013.

SOKAL, Alan; BRICMONT, Jean. Fashionable Nonsense. Postmodern intellectuals' abuse of science. New York: Picador, 1998.

TAVIANI, Ferdinando. Lettera su una Scienza dei Teatri. Teatro e Storia, Bologna, Il Mulino, a. V, n. 2, p. 171-197, oct. 1990.

WALKER, George Richmond Walker. Art, Science and Reality. Bulletin of the Atomic Scientists, Chicago, Educational Foundation for Nuclear Science, p. 9-12, sep. 1964.

WHYMAN, Rose. The Stanislavsky System of Acting. New York: Cambridge University Press, 2008.

Victor Emmanuel Jacono is a theatre maker, educator and researcher whose work focuses primarily on the actor's pedagogy and performative creativity. Linking epistemology, complexity theory and the cognitive sciences, in 2012 he obtained a $\mathrm{PhD}$ in Performance Studies from the University of Rome "La Sapienza". He is a founding member of the Italian Centre for the International Theatre Institute (ITI). E-mail: vjacono@hotmail.com

This unpublished text, reviewed by Ananyr Porto Fajardo, is also published in Portuguese in this issue.

Received in September 10, 2013 Accepted in January 21, 2014 